\title{
An Experimental Study on Unconfined Compressive Strength of Soft Soil-Cement Mixtures with or without GGBFS in the Coastal Area of Vietnam
}

\author{
Son Bui Truong $\left(\mathbb{D}\right.$, Nu Nguyen Thi $\mathbb{D}^{D}$, and Duong Nguyen Thanh \\ Hanoi University of Mining and Geology, No. 18 Vien Street, Duc Thang Ward, Bac Tu Liem District, Hanoi, Vietnam \\ Correspondence should be addressed to Son Bui Truong; buitruongson@humg.edu.vn
}

Received 15 January 2020; Revised 6 June 2020; Accepted 13 June 2020; Published 30 June 2020

Academic Editor: Li Li

Copyright (c) 2020 Son Bui Truong et al. This is an open access article distributed under the Creative Commons Attribution License, which permits unrestricted use, distribution, and reproduction in any medium, provided the original work is properly cited.

\begin{abstract}
Soft soil is widely distributed in Vietnam, especially in the coastal area. In engineering practice, soft soil cannot be used to build any construction and needs to be improved or treated before building construction. In addition, Vietnam has many pig-iron or thermal power plants, which annually produce a huge amount of granulated blast furnace slag (GBFS). Thus, the use of this material for soft soil improvement needs to be considered. This paper presents experimental results on the unconfined compressive strength (UCS) of three Vietnam's soft soils treated with Portland cement and Portland cement with ground granulated blast furnace slag (GGBFS). Binder dosage used in this study is 250,300 , and $350 \mathrm{~kg} / \mathrm{m}^{3}$ with the three different water/cement ratios of $0.8,0.9$, and 1.0, respectively. The research results showed that the UCS of soil-cement mixtures depends on soil type, water/cement ratio, cement type, and binder content. Accordingly, the unconfined compressive strength increased with the increase of binder contents, the decrease of the natural water content of soft soil, water/cement ratios, and clay content. The highest value of UCS of treated soils was found for the soil at Site II with the Portland cement content, cement GGBFS, and water/ cement ratio of $873 \mathrm{~kg} / \mathrm{m}^{3}, 2355 \mathrm{~kg} / \mathrm{m}^{3}$, and 0.8 , respectively. Besides, for all the three soils and two binder types, the water/cement ratio of 0.8 was found to be suitable to reach the highest UCS values of treated soil. The research results also showed that the UCS of treated soil with cement GGBFS was higher than that of treated soil with Portland cement. This indicated the effectiveness of the use of Portland cement with GGBFS in soft soil improvement. There is great potential for reducing the environmental problems regarding the waste materials from pig-iron plants in Vietnam and the construction cost as well.
\end{abstract}

\section{Introduction}

Vietnam is one of the countries with a long coastline of more than $3000 \mathrm{~km} \mathrm{[1].} \mathrm{Plains} \mathrm{are} \mathrm{distributed} \mathrm{along} \mathrm{the} \mathrm{coastline}$ and formed by sedimentation from many rivers such as Red, Thai Binh, Ma, Dong Nai, and Mekong. The stratigraphy of these deltas is very complicated and is formed in the Holocene age, that is, young sediments. These sediments are mainly in soft to very soft state and often make an unfavorable condition for construction activities [1-6]. Recently, the demand for infrastructure development in Vietnam is on the rise. Thus, there is great attention to the areas with poor soil conditions. However, the soil in these areas needs to be improved before building construction. So far, one of the methods that are commonly used for the improvement of soft soil in Vietnam is cement deep mixing (CDM) method [7-11]. This method has been also widely used in the world, especially in southeast Asian countries [12].

Regarding the use of cement for soil improvement, some main properties of soil-cement mixtures, including the unconfined compressive strength, the elastic modulus $\left(E_{50}\right)$, small-strain shear modulus, and strain-dependent shear stiffness, have been widely investigated [12-19]. The unconfined compressive strength (UCS) is one of the most important strength parameters of cement-stabilized soils and has received much attention from the literature [15-17, 20-25]. Abbey et al. [24] indicated that UCS is the most essential parameter to design the cut-off walls for the 
prevention of seepage in water-retaining walls. It was also found that the UCS was an indication of the degree of reaction in the soil-binder-water mixture based on the rate of hardening of the improved mixture. The UCS of soil-cement mixtures is often affected by many factors such as soil properties, the chemical reaction, cementitious constituent [26], and type of mixing method [27]. The development of strength of soil treatment depends on the mineralogy of soils, types and cement content, curing period, and environmental conditions of soft ground [12]. Kitazume and Tersahi [28] indicated that the most important factors that affect the properties of soil-cement columns are the binder type, soil properties, mixing type, and curing conditions.

In general, the CDM method is an economical and effective method for soft soil improvement. This method can significantly reduce the compressibility and permeability of soil and increases the soil bearing capacity and the resistance against liquefaction [25]. However, one of the main limitations of using cement for soil improvement is that the production of cement often consumes a big amount of heating energy and can release a huge amount of carbon dioxide $\left(\mathrm{CO}_{2}\right)$, which results in global warming [29, 30]. Now, there is an increasing trend of using waste materials such as granulated blast furnace slag (GBFS), ground granulated blast furnace slag (GGBFS), fly ash, bottom ash, and steel slag, which can cause a serious problem for the environment in civil engineering practice. The utilization of these materials can reduce the negative impact on the environment and replace the natural materials such as sand, gravel, or even conventional Portland cement. GBFS is an industrial by-product, and production of GBFS consumes less energy and releases less $\mathrm{CO} 2$ emissions rather than the production of Portland cement [29, 31, 32]. GGBFS, a ground product of grinding GBFS, often contains a high content of calcium oxide and silica, which can react with alkali as a pozzolanic reaction to form the cementitious products $[33,34]$. Thus, GGBFS has been widely investigated to partly replace cement in concrete products [35-38] and soil stabilization. For soil stabilization, the GGBFS is often combined with cement, lime for stabilization of soft soil, lateritic soils, and expansive soils for the base and subbase layers in road and pavement applications [34, 39-42]. However, the research on the utilization of GGBFS to partly replace cement in soil improvement using the CDM method is still limited.

In Vietnam, it is predicted that the annual production of GBFS from iron-pig plants in the whole country will be above 7 million tons in 2020 [43]. This waste material often makes a serious problem for soil, water, and air environments in many areas where iron plants are distributed. Our previous study showed that GBFS has the same effect as the coal ash from thermal power plants on the environment in Vietnam [44]. Thus, the amount of GBFS must be reduced for environment management. In Vietnam, GBFS can be reused as base material for rural roads [45]. However, there is still a huge amount of GBFS and there is a great potential of using GGBFS, which is a ground product of GBFS, in combination with cement for soil improvement. As mentioned above, the cement-stabilized soil, especially the CDM method, is very necessary and popular in Vietnam. Hence, the combination of GGBFS with cement for soft soil improvement using deep cement mixing method is very practical in Vietnam. In this study, Portland cement and GGBFS will be used to mix with some types of soft soil distributed along the Vietnamese coastal area to investigate the applicability of GGBFS in soft soil treatment. In addition, some factors affecting the unconfined compressive strength of soil-cement and soil-cement GGBFS mixtures such as types of soil, binder content, and water/cement ratios will be evaluated. Accordingly, a number of remolded samples of soil-cement and soil-cement GGBFS were prepared and tested in the laboratory.

\section{Materials and Methods}

2.1. Materials. The soil samples were taken in boreholes from different locations in the coastal area of Vietnam, including Thanh Hoa province (Site I), Nghe An province (Site II), and Ho Chi Minh city (Site III). The soil samples were first determined the physical properties, unconfined compressive strength, and particle size analysis. The tests were conducted in accordance with the ASTM standards. According to the Unified Soil Classification System (USCS), three soils are classified as $\mathrm{CH}-$ Fat clay, SC-Clayey sand, and $\mathrm{CH}-\mathrm{Fat}$ clay, respectively. Some properties of these soils are provided in Table 1 , and the particle size distribution is shown in Figure 1. It can be seen that these soils have high water content and void ratio. The natural water contents of soft clay in Site I and Site III are higher than those in Site II. These soils are in a soft state and their strengths need to be improved to meet the construction requirements.

The cement used in this study was Portland cement (PCB 40) and Portland cement with ground granulated furnace blast $\left(\mathrm{PCB}_{\mathrm{BFS}} 40\right)$ made by Ha Tien company. The chemical compositions of these types of cement are shown in Table 2. $\mathrm{PCB}_{\mathrm{BFS}} 40$ has $40 \sim 50 \%$ GGBFS content.

Some properties of $\mathrm{PCB} 40$ and $\mathrm{PCB}_{\mathrm{BFS}} 40$ are shown in Table 3.

\subsection{Methods}

2.2.1. Investigating the Unconfined Compressive Strength of Soil-Cement-GGBFS Mixture. In this study, the effects of soil types, cement types, cement contents, and water/cement ratios on the UCS values of treated soil will be investigated. To investigate the effect of soil type, three different types of soft soil as mentioned above were used to mix with cement PCB40 and cement $\mathrm{PCB}_{\mathrm{BFS}} 40$. From there, the effects of two types of cement (Portland cement and Portland cement with GGBFS) on the UCS were also evaluated.

To study the effect of cement content on the unconfined compressive strength of soil-cement mixtures, a group of tests were conducted on three dosage rates, which were 250, 300 , and $350 \mathrm{~kg} / \mathrm{m}^{3}$. The cement (cement GGBFS) proportion is defined as the weight of binder added per unit volume of the soil to be treated, expressed in $\mathrm{kg} / \mathrm{m}^{3}$ [46].

Variation of unconfined compressive strength under the effect of different water/cement ratios was described at 28- 
TABle 1: Physicomechanical properties of soft soil.

\begin{tabular}{|c|c|c|c|c|}
\hline No. & Properties of soil & Site I & Site II & Site III \\
\hline 1 & Water content, $W(\%)$ & 81.7 & 69.7 & 98.0 \\
\hline 2 & Unit weight, $\rho, \mathrm{g} / \mathrm{cm}^{3}$ & 1.49 & 1.55 & 1.45 \\
\hline 3 & Dry unit weight, $\rho_{c}, \mathrm{~g} / \mathrm{cm}^{3}$ & 0.82 & 0.91 & 0.73 \\
\hline 4 & Specific gravity, $\rho_{s}, \mathrm{~g} / \mathrm{cm}^{3}$ & 2.68 & 2.66 & 2.65 \\
\hline 5 & Void ratio, $e$ & 2.268 & 1.923 & 2.630 \\
\hline 6 & Liquid limit, LL (\%) & 87.8 & 59.7 & 78.4 \\
\hline 7 & Plastic limit, PL & 33.0 & 28.8 & 31.5 \\
\hline 8 & Plasticity index, PI & 54.8 & 30.9 & 46.9 \\
\hline 9 & Liquidity index, Is & 0.89 & 1.32 & 1.35 \\
\hline 10 & Unconfined compressive strength, UCS, $\mathrm{kPa}$ & 21.3 & 15.9 & 11.2 \\
\hline
\end{tabular}

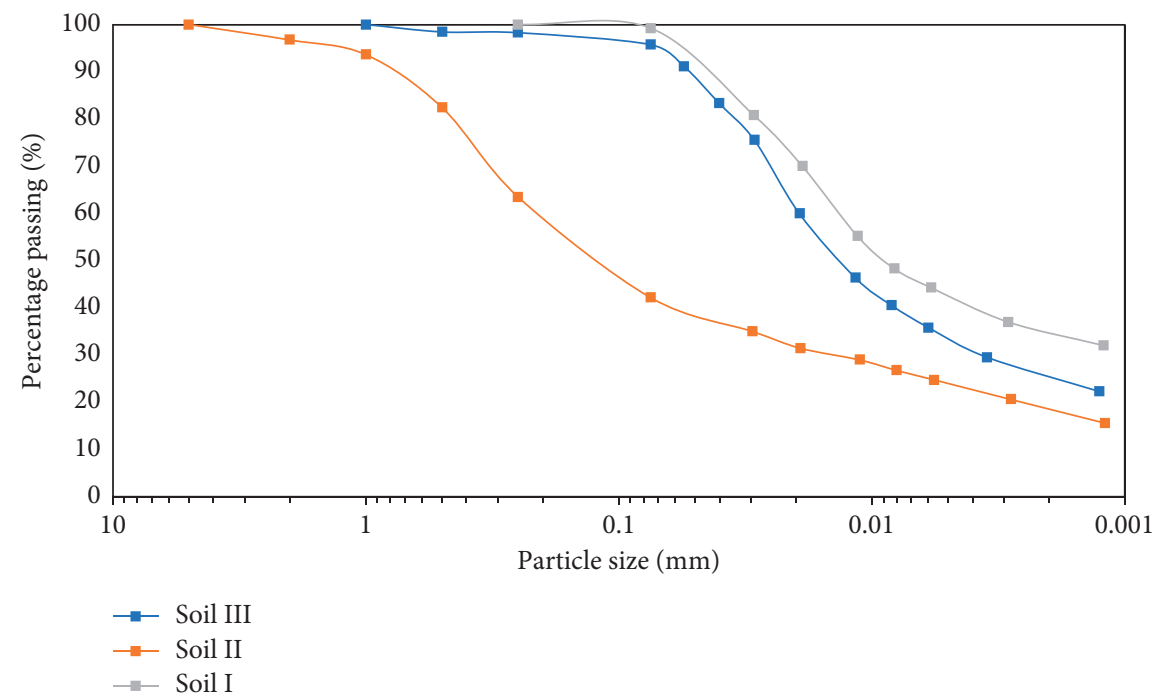

FIgURe 1: Particle size distribution curve.

TABle 2: Chemical compositions of Portland cement and GGBFS.

\begin{tabular}{lcccccccc}
\hline \multirow{2}{*}{ Type of material } & \multicolumn{9}{c}{ Oxide (\%) } \\
& $\mathrm{SiO}_{2}$ & $\mathrm{Al}_{2} \mathrm{O}_{3}$ & $\mathrm{CaO}$ & $\mathrm{Fe}_{2} \mathrm{O}_{3}$ & $\mathrm{MgO}$ & $\mathrm{SO}_{3}$ & $\mathrm{~K}_{2} \mathrm{O}$ & $\mathrm{Na}_{2} \mathrm{O}$ \\
\hline PCB40 & 22 & 8 & 62 & 3 & 2 & 2 & 0.6 \\
GGBFS & 30 & 10 & 45 & - & 2 & - & - \\
\hline
\end{tabular}

TABle 3: Physical-chemical properties of Portland cement and Portland cement with GGBFS.

\begin{tabular}{lccc}
\hline No. & Physical-chemical properties & PCB40 & PCB ${ }_{\text {BFS }} 40$ \\
\hline 1 & Specific gravity, $\rho_{s}, \mathrm{~g} / \mathrm{cm}^{3}$ & 3.10 & 3.12 \\
2 & Compressive strength at 3-day curing, MPa & 25.6 & 29.2 \\
3 & Compressive strength at 28-day curing, MPa & 52.5 & 63.4 \\
\hline
\end{tabular}

day curing. In this study, three different water/cement (W/ C) ratios of $0.8,0.9$, and 1.0 were investigated at three different soil types, three different binder contents, and two types of cement.

2.2.2. Sample Preparation and Testing. The undisturbed soil samples were collected from the borehole at three sites. The soil samples were stored at the room humidity and temperature to retain the moisture content. The soil was then mixed with Portland cement and Portland cement with GGBFS (cement GGBFS). The mixtures of soil-binder were prepared with $W / C$ ratios of $0.8,0.9$, and 1.0. The contents of PCB40 and $\mathrm{PCB}_{\mathrm{BFS}} 40$ are shown in Table 4.

A metal mold with $50 \mathrm{~mm}$ inner diameter and $100 \mathrm{~mm}$ length was used for the preparation of treated samples. The treated samples were created by mixing soil, cement (cement GGBFS), and water. The amounts of Portland cement and cement GGBFS and water/cement ratios were used as shown in Table 4. Natural soil samples were firstly mixed for 5-10 
TABle 4: Contents of PCB40 and $\mathrm{PCB}_{\mathrm{BFS}} 40$ used in this study.

\begin{tabular}{lccc}
\hline Location & & Binder dosage $\left(\mathrm{kg} / \mathrm{m}^{3}\right)$ & \\
& PCB40 & PCB $_{\mathrm{BFS}} 40$ & Water cement ratios \\
Site I & 250 & 250 & 300 \\
& 300 & 350 & $0.8,0.9$, and 1.0 \\
\hline \multirow{2}{*}{ Site II } & 350 & 250 & $0.8,0.9$, and 1.0 \\
& 250 & 300 & 350 \\
Site III & 300 & 200 & $0.8,0.9$, and 1.0 \\
& 350 & 250 & 300 \\
\hline
\end{tabular}

minutes using a mixer; then the slurry of binder-water was poured into it and mixed again for 5-10 minutes. The slurry of mixtures was then placed into a metal mold in three layers. The surface of the sample in the mold was flattened and weighted to determine the mass. The samples were then sealed tightly using a plastic sheet to prevent loss of moisture content. All the treated samples were subjected to cure at room humidity and room temperature of $25 \pm 2^{\circ} \mathrm{C}$ for 28 days before testing. The unconfined compressive strength tests were carried out on 108 cylindrical specimens of soft soil-Portland cement mixtures and 108 cylindrical specimens of soil-cement GGBFS mixtures. The unconfined compressive strength tests were performed on these specimens in accordance with ASTM D 2166. The rate of loading for the unconfined compressive tests was $1 \mathrm{~mm} / \mathrm{min}$.

\section{Results and Discussion}

Specimens were tested at three different binder contents $\left(250 \mathrm{~kg} / \mathrm{m}^{3}, 300 \mathrm{~kg} / \mathrm{m}^{3}\right.$, and $\left.350 \mathrm{~kg} / \mathrm{m}^{3}\right)$ and three water/ cement ratios $(0.8,0.9$, and 1.0$)$. The results of unconfined compressive strength (UCS) are shown in Table 5 and Figures 2-4.

3.1. Effect of Soil Type and Binder Content on the Unconfined Compressive Strength. The variations of UCS values with binder content and how soil type influences the UCS values are given in Figures 5-7. The experimental results show that the UCS values of soil-cement mixture and soil-cementGGBFS mixtures at Sites I, II, and III are different. At the same W/C ratio of 0.8 (Figure 5), the UCS values of soilcement mixture treated for Site I ranged from 728 to $873 \mathrm{kPa}$, for Site II ranged from 808 to $951 \mathrm{kPa}$, and for Site III ranged from 695 to $783 \mathrm{kPa}$. Meanwhile, the UCS values of soil-cement-GGBFS mixtures for Site I ranged from 2045 to $2355 \mathrm{kPa}$, for Site II ranged from 2449 to $2816 \mathrm{kPa}$, and for Site III ranged from 1961 to $2371 \mathrm{kPa}$.

Similar to the $W / C$ ratio of 0.8 , at the $W / C$ ratio of 0.9 (Figure 6), the UCS values of soil-cement mixture treated for Site I, Site II, and Site III ranged from 706 to $838 \mathrm{kPa}$, from 752 to $863 \mathrm{kPa}$, and from 673 to $727 \mathrm{kPa}$, respectively. The UCS values of soil-cement-GGBFS mixture for Site I, Site II, and Site III ranged from 1733 to $2070 \mathrm{kPa}$, from 2359 to $2660 \mathrm{kPa}$, and from 1707 to $2056 \mathrm{kPa}$, respectively.
The UCS results for specimens mixed at the same $W / C$ ratio of 1.0 (Figure 7) varied from 648 to $778 \mathrm{kPa}$, from 720 to $801 \mathrm{kPa}$, and from 653 to $703 \mathrm{kPa}$ for Sites I, II, and III, respectively. The UCS values of soil-cement-GGBFS mixture for Site I varied from 1630 to $1965 \mathrm{kPa}$, for Site II varied from 2241 to $2545 \mathrm{kPa}$, and for Site III varied from 1592 to $1961 \mathrm{kPa}$, respectively.

In general, for all the water/cement ratios and binder contents, the highest value of UCS of treated soils is found for the soil at Site II, followed by the soil at Site I and that at Site III. Concerning the physical properties of samples used in Table 1, it can be seen that the UCS values of treated soil tend to decrease with the increase of clay content and liquid limit of the original soils. As reported by Farouk and Shahien [46], the compressive strength of the cemented soil decreased with the increase in the fines content of untreated soil. The treated soil at Site III has the lowest value of UCS, since the untreated soil has the highest clay content and the highest liquid limit. Horpibulsuk et al. [22] indicated that the clay-water/cement ratio, that is, the ratio of the initial water content of the clay $\left(w_{c}\right)$ to the cement content, plays an important role in the mix design in the laboratory and in analyzing the strength and deformation behavior of soilcement mixtures. Accordingly, the increase of the claywater/cement ratio leads to a decrease in the UCS value of soil-cement mixture. Binder content plays an important role in treated soil, since it strengthens the fabric at the intercluster spacing of treated soil. In soft clay, water is already present and is not free, but it can interact with the clay [46].

\subsection{Effect of Binder Content on the Unconfined Compressive} Strength. The effects of binder content on unconfined compressive strength (UCS) are presented in Figures 5-7. The unconfined compressive strengths of cement-treated soil (S-C) and cement-GGBFS-treated soil (C-F-S) range from 648 to $951 \mathrm{kPa}$ and from 1539 to $2816 \mathrm{kPa}$, respectively. The lowest value of unconfined compressive strength is found in a specimen that has the smallest cement content $\left(250 \mathrm{~kg} / \mathrm{m}^{3}\right)$. The highest one is observed in the specimen that has the highest cement content $\left(350 \mathrm{~kg} / \mathrm{m}^{3}\right)$. It can be seen that the increase of unconfined compressive strength is attributed to the increase in cement content or cement GGBFS content. This is consistent with the research result of Asturias and Lorenzo [47]. It is possible that the increase in 
TABLE 5: Results of unconfined compressive strength at 28-day curing.

\begin{tabular}{|c|c|c|c|c|c|c|c|c|}
\hline \multirow{3}{*}{ No. } & \multirow{3}{*}{ Binder dosage $\left(\mathrm{kg} / \mathrm{m}^{3}\right)$} & \multirow{3}{*}{ Water cement ratios } & \multicolumn{6}{|c|}{ UCS $(\mathrm{kPa})$} \\
\hline & & & \multicolumn{2}{|c|}{ Site I } & \multicolumn{2}{|c|}{ Site II } & \multicolumn{2}{|c|}{ Site III } \\
\hline & & & PCB40 & $\mathrm{PCB}_{\mathrm{BFS}} 40$ & РCB40 & $\mathrm{PCB}_{\mathrm{BFS}} 40$ & РCB40 & $\mathrm{PCB}_{\mathrm{BFS}} 40$ \\
\hline 1 & 250 & & 728 & 2045 & 808 & 2449 & 695 & 1961 \\
\hline 2 & 300 & 0.8 & 808 & 2205 & 912 & 2743 & 757 & 2119 \\
\hline 3 & 350 & & 873 & 2355 & 951 & 2816 & 783 & 2223 \\
\hline 4 & 250 & & 706 & 1733 & 752 & 2359 & 673 & 1622 \\
\hline 5 & 300 & 0.9 & 770 & 1938 & 814 & 2481 & 710 & 1867 \\
\hline 6 & 350 & & 838 & 2070 & 863 & 2660 & 727 & 1948 \\
\hline 7 & 250 & & 648 & 1630 & 720 & 2241 & 653 & 1539 \\
\hline 8 & 300 & 1.0 & 698 & 1848 & 755 & 2437 & 683 & 1783 \\
\hline 9 & 350 & & 778 & 1965 & 801 & 2545 & 703 & 1827 \\
\hline
\end{tabular}

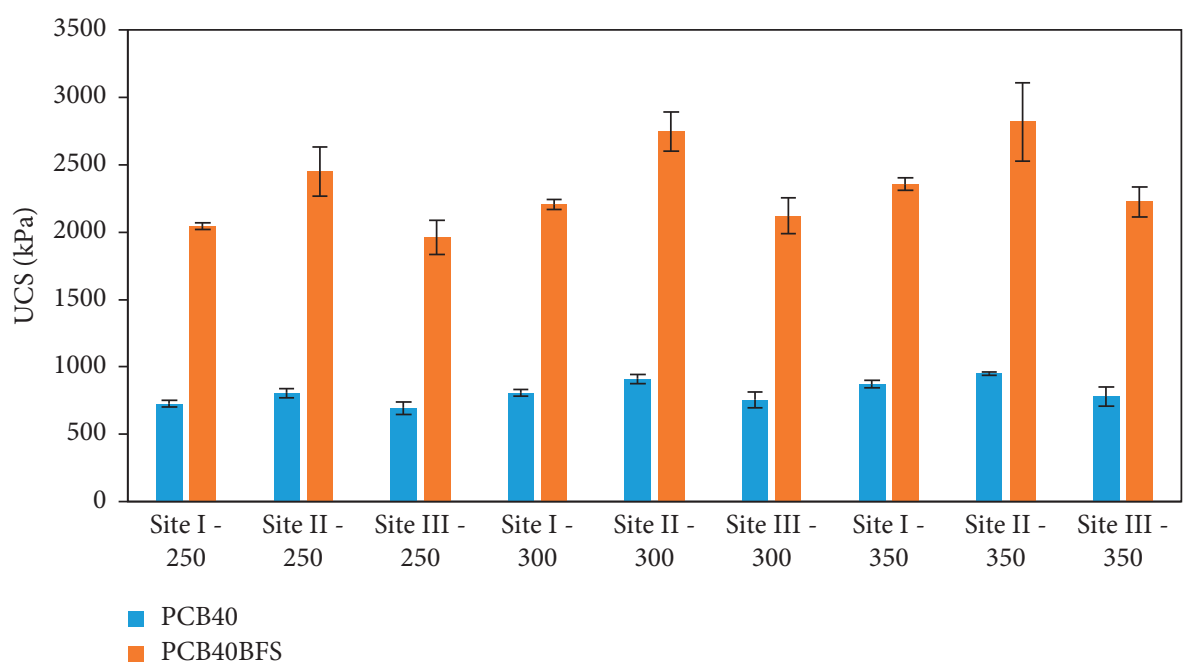

Figure 2: The unconfined compressive strength at $W / C=0.8$.

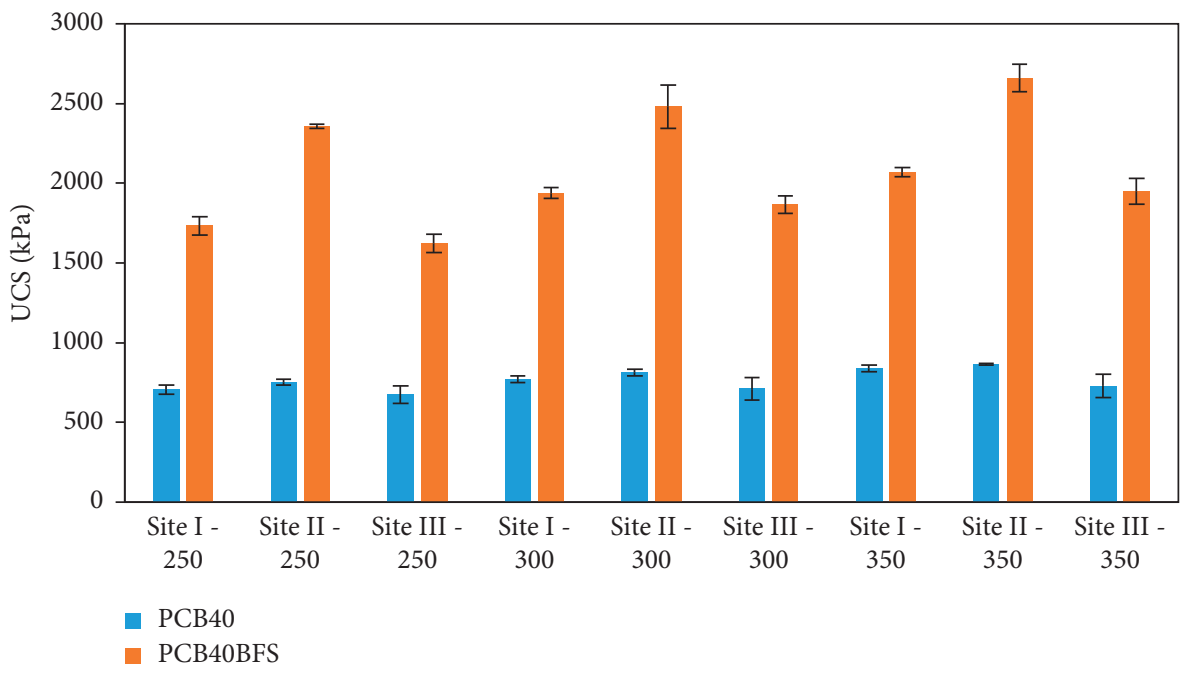

FIgURE 3: The unconfined compressive strength at $W / C=0.9$.

UCS of the treated soil is due to the reaction between cement and pore water and results in cation exchange and formation of cement products that bind the soil particles together [41].
Farouk and Shahien [46] also showed that the strength, stiffness, and brittleness of the cemented soil increased with the increase of cement dose. 


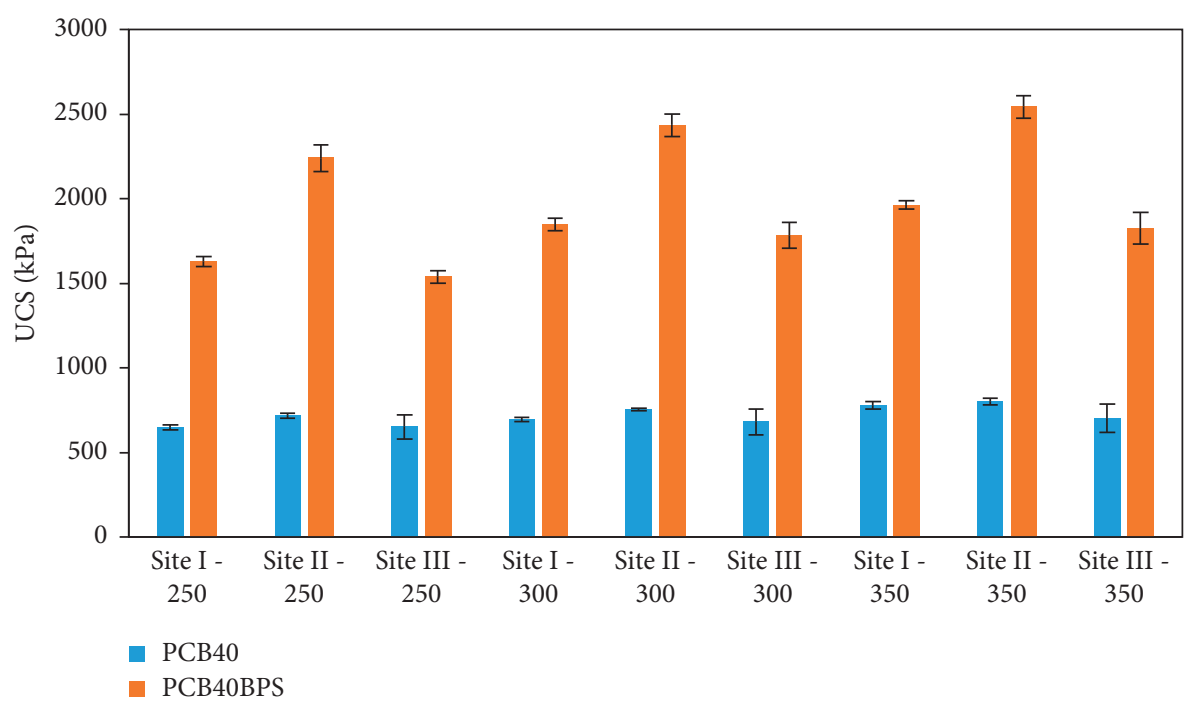

FIgure 4: The unconfined compressive strength at $W / C=1.0$.

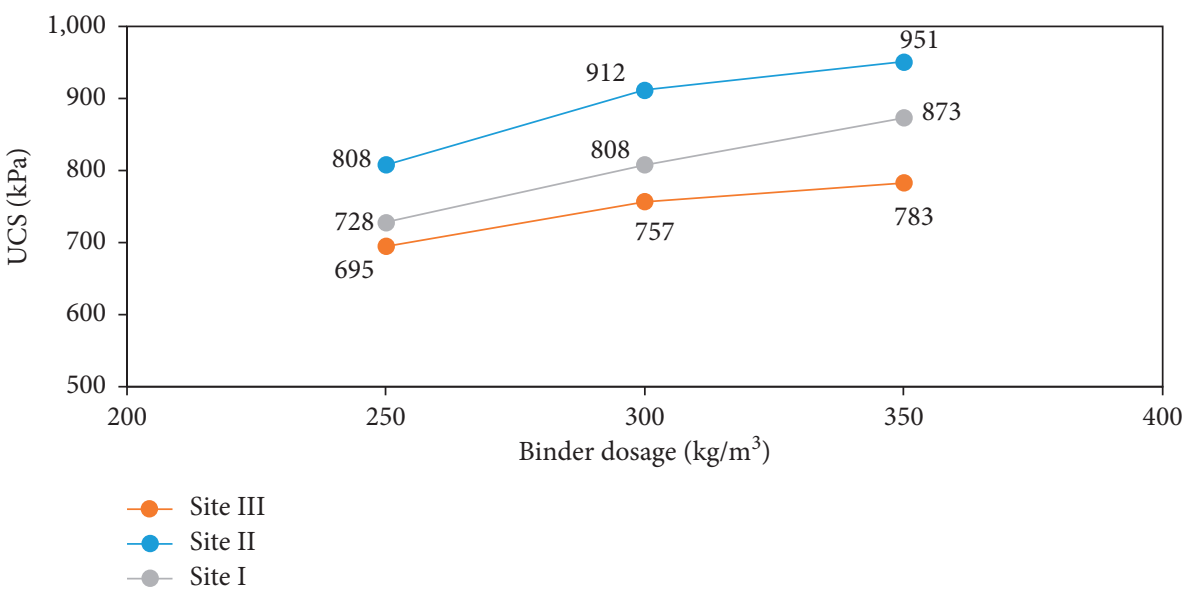

(a)

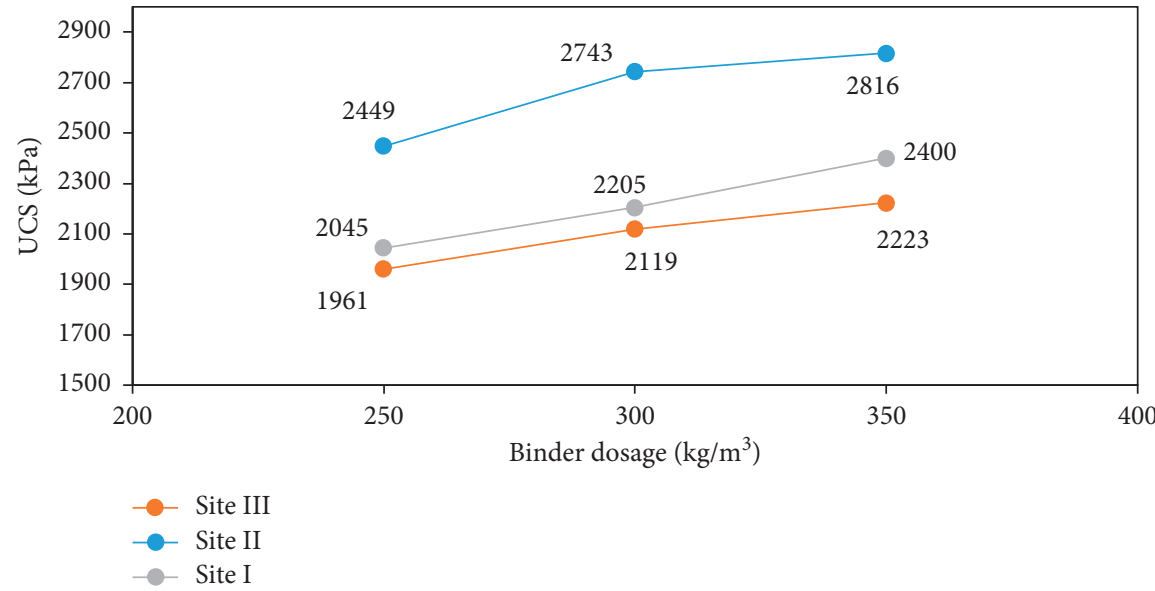

(b)

Figure 5: The unconfined compressive strength at $W / C=0.8$. (a) Cement-treated soil. (b) Cement-GGBFS-treated soil. 


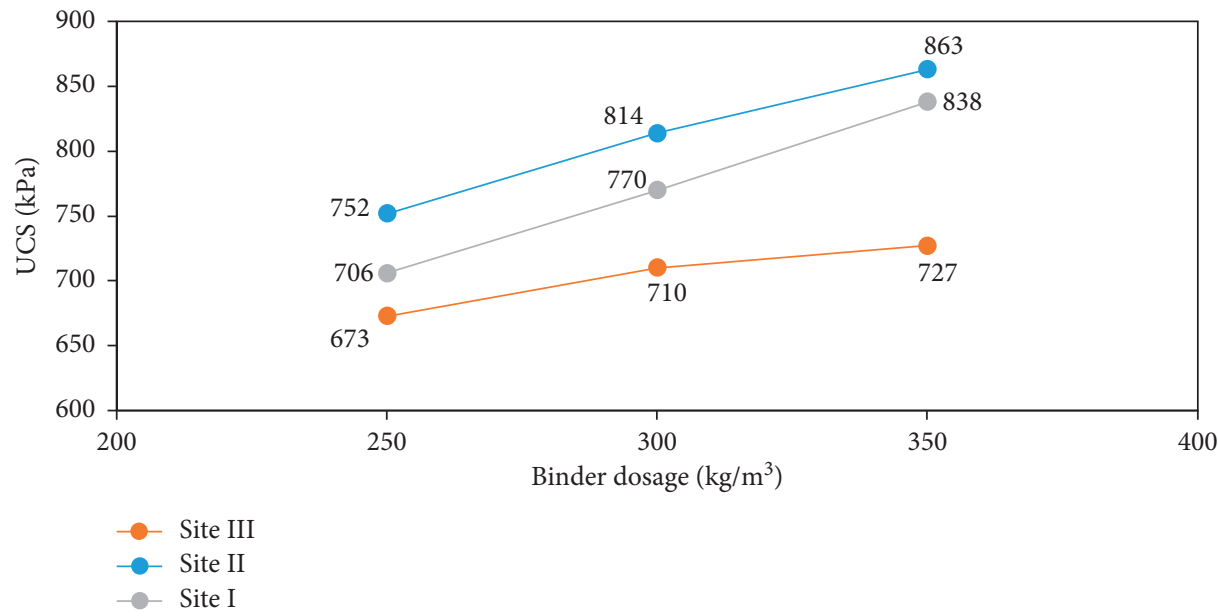

(a)

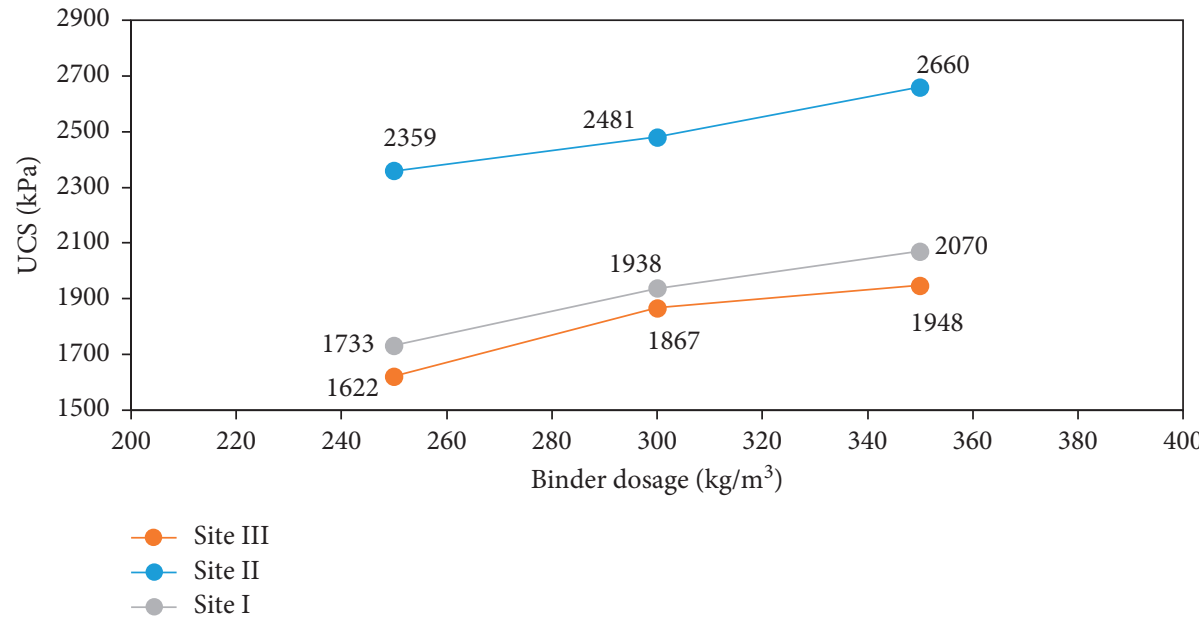

(b)

Figure 6: The unconfined compressive strength at $W / C=0.9$. (a) Cement-treated soil. (b) Cement-GGBFS-treated soil.

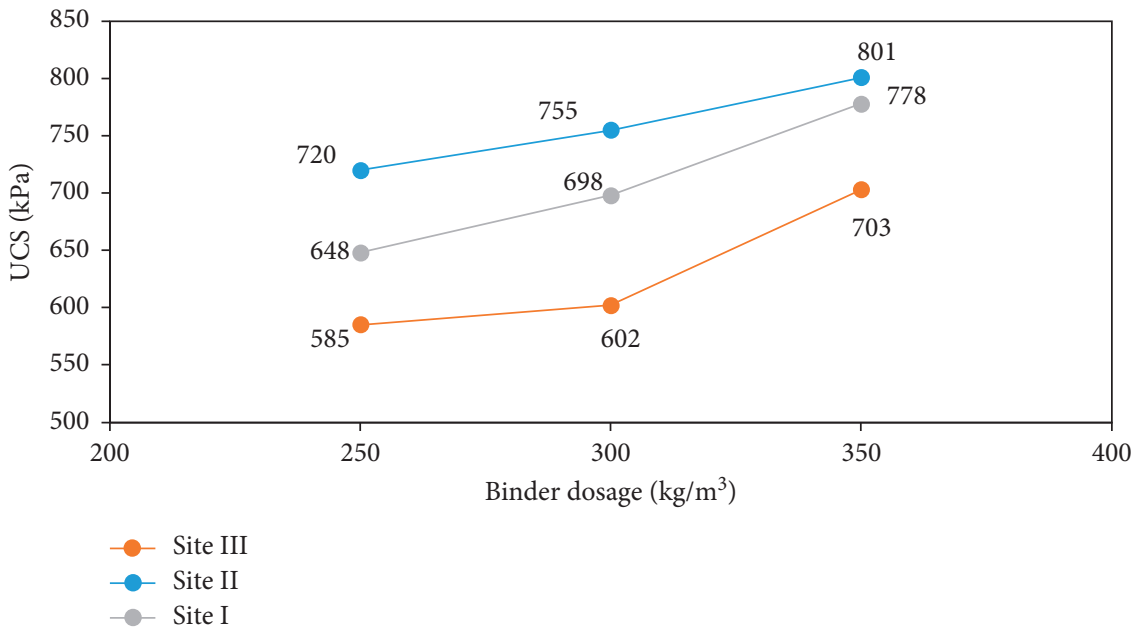

(a)

Figure 7: Continued. 


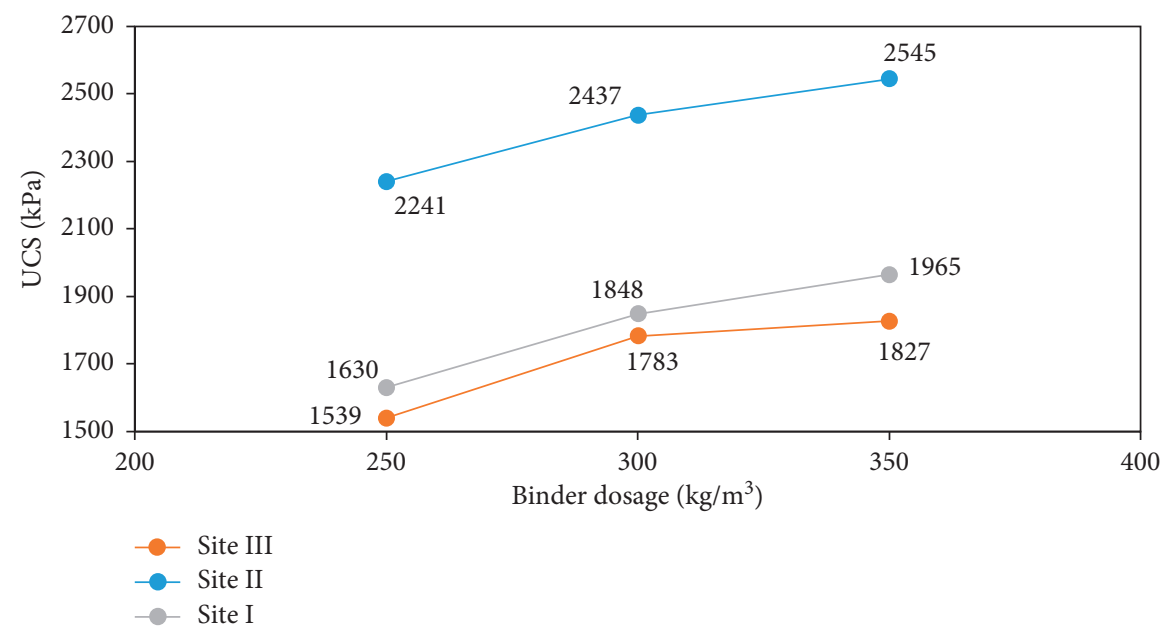

(b)

Figure 7: The unconfined compressive strength at $W / C=1.0$. (a) Cement-treated soil. (b) Cement-GGBFS-treated soil.

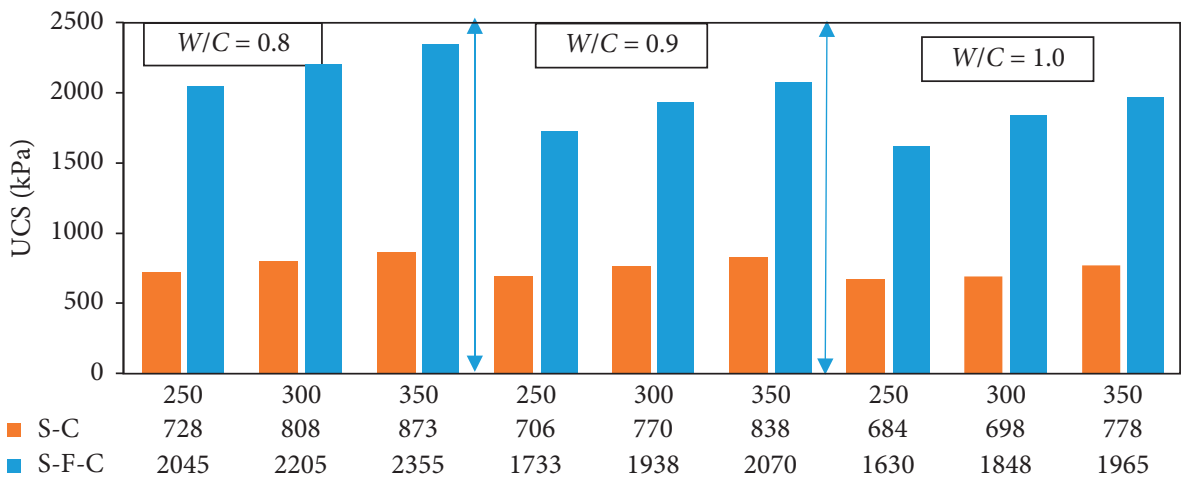

Figure 8: The unconfined compressive strength at $W / C$ ratios of $0.8,0.9$, and 1.0 at Site I.

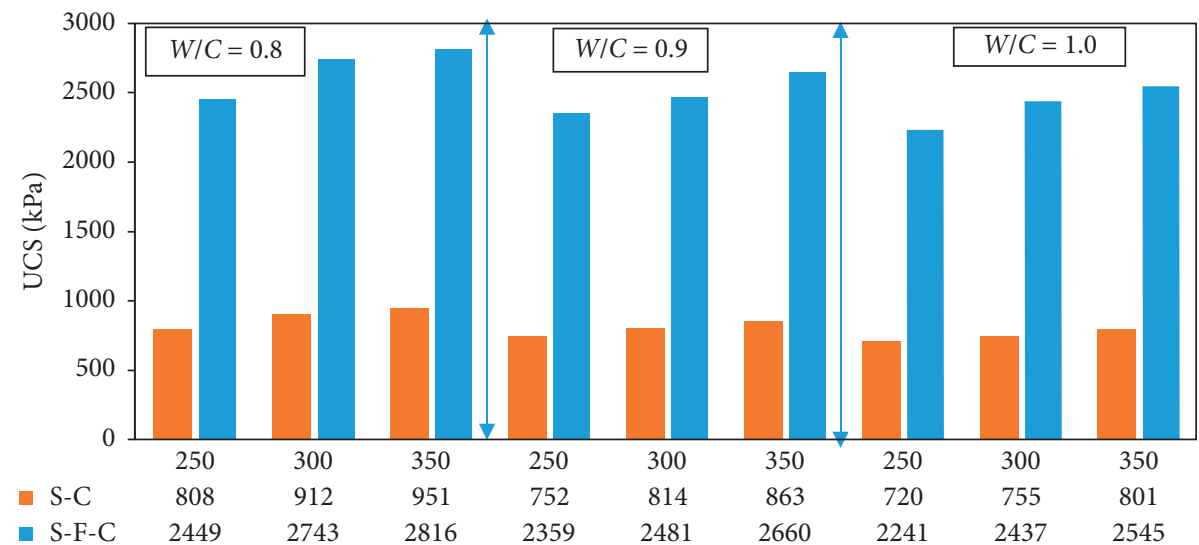

Figure 9: The unconfined compressive strength at $W / C$ ratios of $0.8,0.9$, and 1.0 at Site II.

3.3. Effects of Cement GGBFS on the Unconfined Compressive Strength. The variations in unconfined compressive strength in terms of different percentages of cement GGBFS contents are provided in Figures 8-10. It can be seen that the increase of cement GGBFS increased the unconfined compressive strength. The unconfined compression strength of soil treated with cement GGBFS $\left(\mathrm{PCB}_{\mathrm{BFS}} 40\right)$ is higher than that of soil treated with cement (PCB40). The unconfined compressive strength of soil treated with PCB40 at Sites I, II, and III was 2.45 2.80, 2.96 3.22, and 2.35 2.83 times lower than the unconfined compressive strength of soil treated with $\mathrm{PCB}_{\mathrm{BFS}} 40$, 


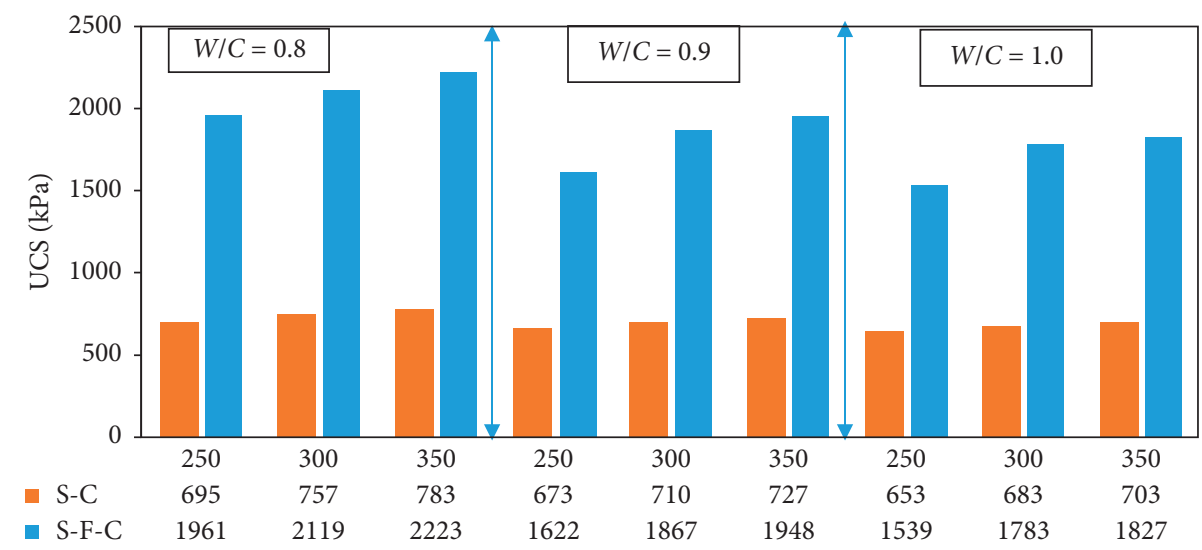

Figure 10: The unconfined compressive strength at $W / C$ ratios of $0.8,0.9$, and 1.0 at Site III.

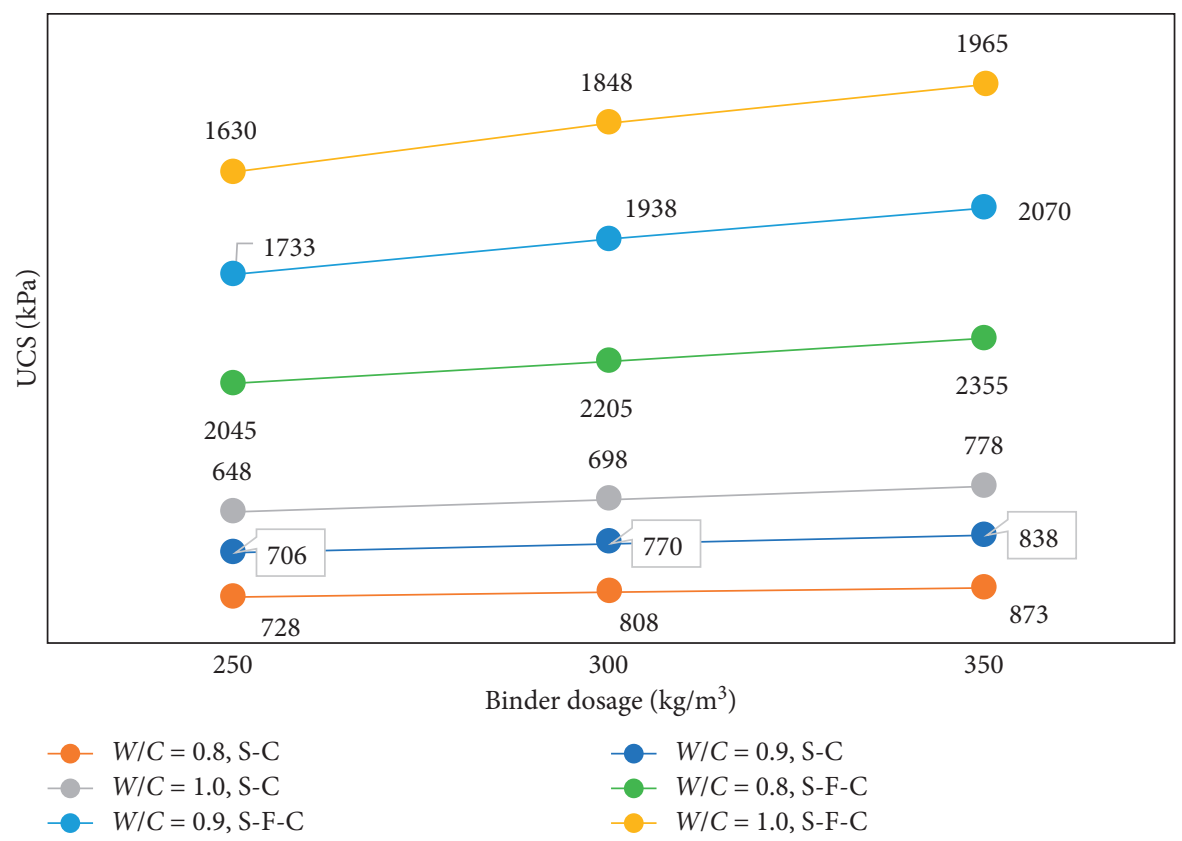

FIGURE 11: The unconfined compressive strength of cement-soil and cement-GGBFS-soil treated at different $W / C$ ratios at Site I.

respectively. It was believed to be due to the effect of GGBFS, which makes higher reaction than the cement without GGBFS. The presence of GGBFS containing high $\mathrm{CaO}$ content will increase cementitious products through a pozzolanic reaction. In addition, the size of particles may increase due to the flocculation and then results in an increase in strength $[19,20]$. Moreover, the increase in strength may also be due to the possibility of suction development in pore fluid because of partial saturation of the improved samples after curing [48]. The results of the present study indicated that the cement GGBFS can reduce the amount of cement used for the improvement of soft soil. Pathak et al. [49] also reported that the increase in the percentage of GGBFS could lead to considerably increasing the strength and reducing pavement thickness for improvement of the subgrade layer.
3.4. Effect of the W/C on the Unconfined Compressive Strength of Soil Treatment. Figures 11-13 illustrate the variation in unconfined compressive strength of soil-cement mixtures and soil-cement-GGBFS mixtures with different water/cement $(W / C)$ ratios. The highest UCS corresponds to specimens having the lowest $W / C$ ratio. The smallest UCS corresponds to the specimen that has the highest $W / C$ ratio. It can be observed that the unconfined compressive strength, UCS, decreased with the increasing $W / C$ ratio. With the increase of $W / C$ from 0.8 to 1.0, the unconfined compressive strength of S-C mixtures decreased from 3.02\% to $13.61 \%$, from $6.93 \%$ to $17.21 \%$, and from $3.16 \%$ to $10.21 \%$ at Site I, Site II, and Site III, respectively. For S-F-C mixtures, the UCS at Site I, Site II, and Site III decreased from $12.1 \%$ to $20.29 \%$, from $3.67 \%$ to $11.1 \%$, and from $11.89 \%$ to $21.51 \%$, respectively, when the $\mathrm{W} / \mathrm{C}$ ratios increased from 0.8 to 1.0. 


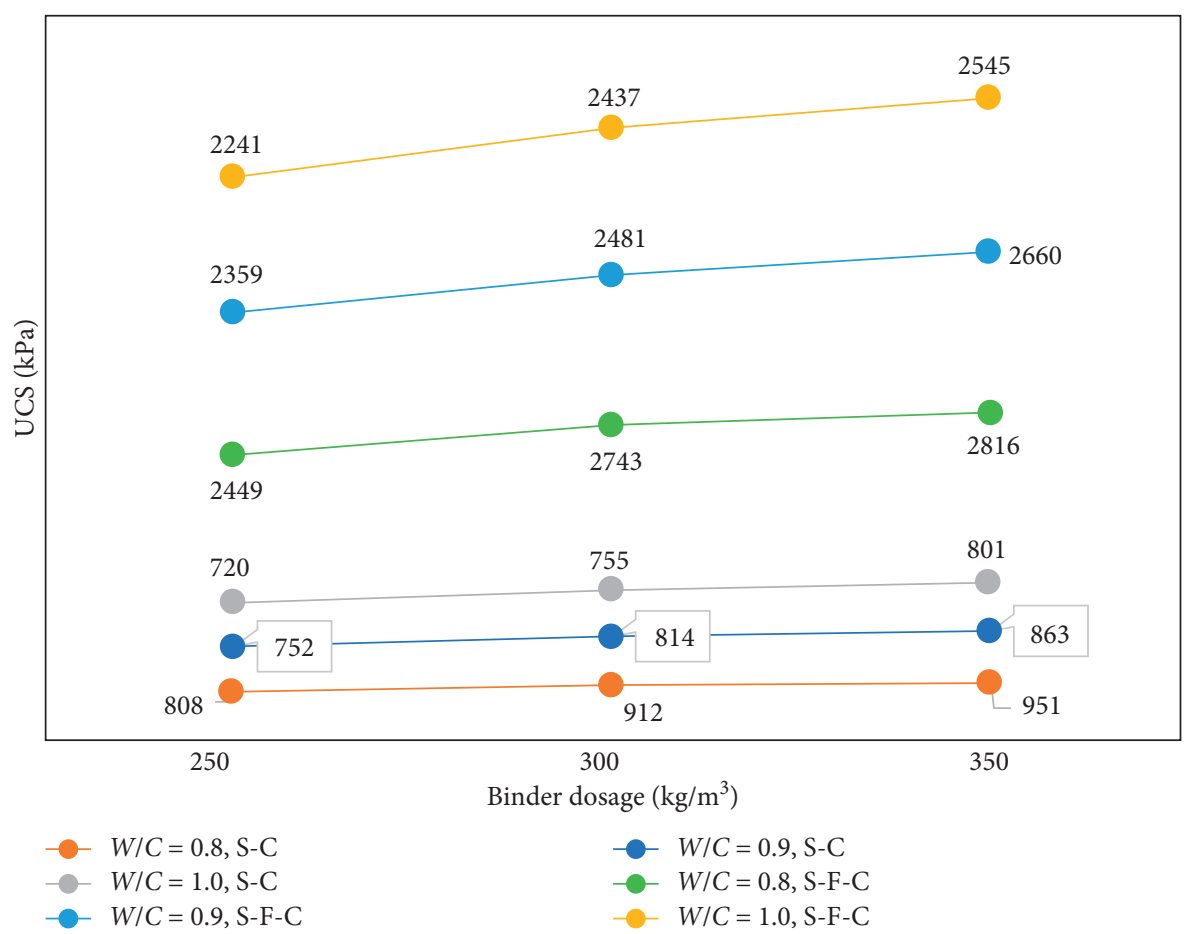

FIGURE 12: The unconfined compressive strength of cement-soil and cement-GGBFS-soil treated at different $W / C$ ratios at Site II.

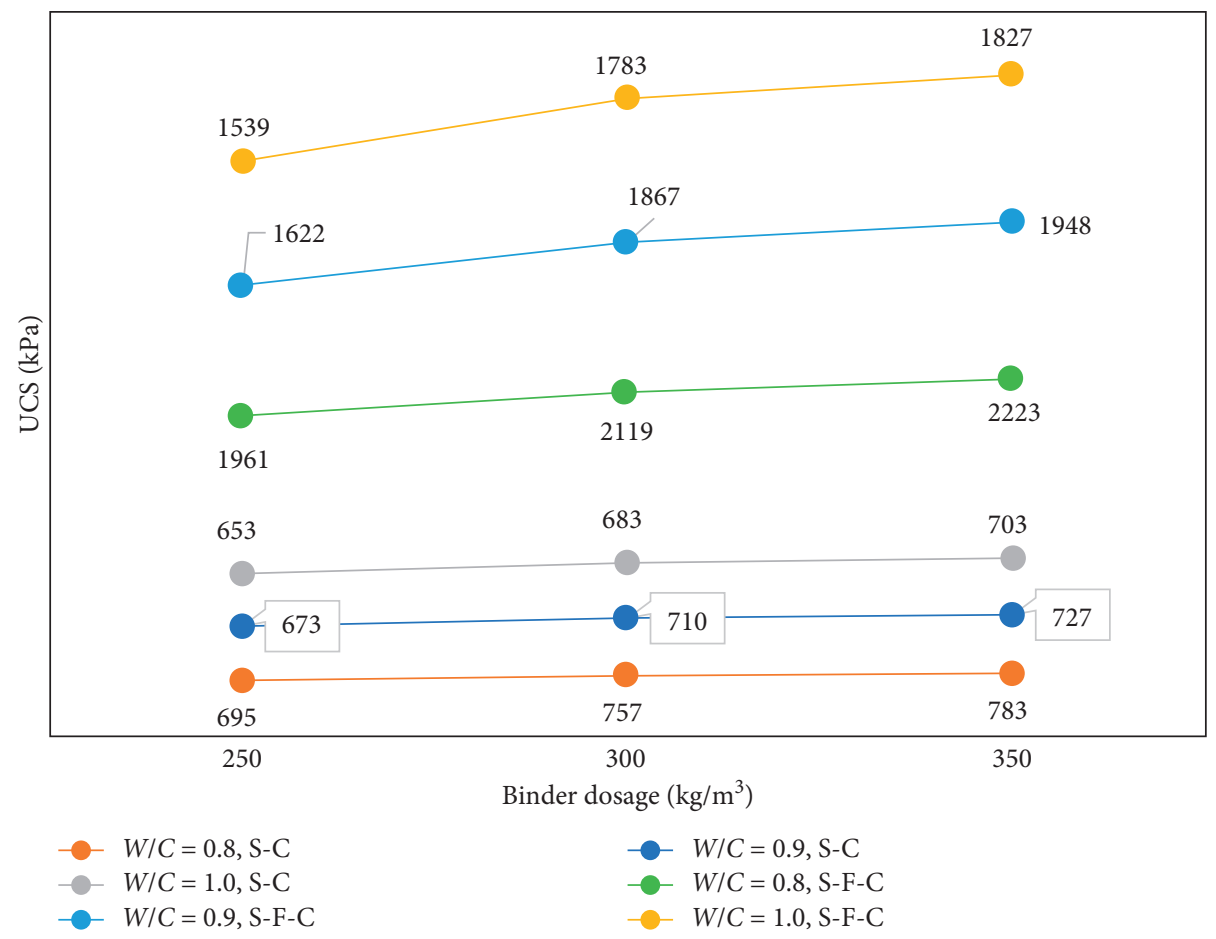

FIGURE 13: The unconfined compressive strength of cement-soil and cement-GGBFS-soil treated at different $W / C$ ratios at Site III.

It is also observed by Farouk and Shahien [46] that the compressive strength decreased with the increase in water/ cement ratio. It is also consistent with the investigation of Pathivada [50] at three different cement ratios of $0.8,1.0$, and 1.3. It is in good agreement with that achieved by Liu et al. [51] that if water content was less than 0.9, CDM (cement deep mixing) behaves better in terms of strength, if water content was within 0.9 1.0, DJM (dry jet mixing) and CDM had a comparative effect, and if water content ratio was larger than 1.0, DJM behaved better. It was believed that the decrease of UCS is due to excess water required for cement hydration [52]. When the water/cement ratio increases, the 
relative cement content decreases and this increases void ratio and water content of the soil-cement [51].

\section{Conclusions}

Based on this investigation, the following observation and conclusions are made as follows.

The effect of soil types on UCS was evaluated using three soils along the coastline of Vietnam and two types of cement. The research result shows that, for all the binder contents and the water/cement ratios, the highest UCS value is observed for the soil at Site II. In addition, for the three types of soil and three contents of binder, the water/cement ratio of 0.8 results in the highest UCS value of treated soil.

The unconfined compressive strength of stabilized soil decreases with the increase in clay fraction and liquid limit of the original soil. Besides, it also decreases with the increase of water/cement ratios and the natural water content of clay and the decrease of binder contents.

The use of Portland cement with GGBFS (cement GGBFS) is more effective than Portland cement in the improvement of soft soils. Thus, the cement GGBFS has shown great potential for soft soil improvement in Vietnam. This will help reduce both the environmental pollution and the construction cost.

\section{Data Availability}

The data used to support the findings of this study are included in the published article.

\section{Conflicts of Interest}

The authors declare that there are no conflicts of interest regarding the publication of this paper.

\section{Acknowledgments}

The authors would like to acknowledge the support of Ministry of Education and Training and Hanoi University of Mining and Geology to complete this paper.

\section{References}

[1] N. T. Nu, N. T. Duong, and N. V. Phong, "The effects of salt contents on the geotechnical properties of some soft soils in the coastal area of Vietnam," Journal of Mining and Earth Sciences, vol. 33, 2019.

[2] T. T. Phuc and P. H. Giao, "Geotechnical properties of hai phong and ninh binh clays in the red river Delta," Geotechnics for Sustainable Infrastructure Development, Springer, Berlin, Germany, 2020.

[3] N. D. Quang and P. H. Giao, "Improvement of soft clay at a site in the Mekong Delta by vacuum preloading," Geomechanics and Engineering, vol. 6, no. 5, pp. 419-436, 2014.

[4] P. H. Giao and D. H. Hien, "Geotechnical characterization of soft clay along a highway in the red river Delta," International Journal of Low-Carbon Technologies, vol. 9, no. 1, pp. 18-27, 2007.

[5] N. T. Nu, D. M. Toan, and N. V. Tinh, "Determining the parameters of consolidation of amQ22-3 soft to very soft clay
(CL, CH) distributed in Soc Trang area for calculating settlement of soil and ground improvement by vertical drains method," Journal of Mining and Earth Sciences, vol. 55, no. 8, pp. 32-39, 2011.

[6] N. T. Nu, H. T. Phi, and B. T. Son, "Determination of particles and minerals content in soft clay soil of the Mekong delta coastal provinces, southern Vietnam for inorganic adhesives stabilization," Iraqi Journal of Science, vol. 61, pp. 791-804, 2020.

[7] Y. Shinohara and N. Kohyama, "Quantitative analysis of tridymite and cristobalite crystallized in rice husk ash by heating," Industrial Health, vol. 42, no. 2, pp. 277-285, 2004.

[8] K. Suzuki, H. Usui, T. Sasai, A. Kojima, M. Nozu, and H. T. Nguyen, "Cement deep mixing applied to soft clay in mekong delta," in Proceedings of the Sri Lankan Geotechnical Society's First Conference on Soil and Rock Engineering, Colombo, Sri Lanka, August 2007.

[9] L. Van Bui and B. T. Pham, "Experimental research for determination of basic parameters of soil improved by cement," International Journal of Applied Engineering Research, vol. 13, no. 6, pp. 3926-3931, 2018.

[10] M. N. Vu and Q. H. Le, "Large soil-cement column applications in Vietnam," in Geotechnics for Sustainable Infrastructure Development, Springer, Berlin, Germany, 2020.

[11] P. T. A. Vu, "Ground improvement using soil-cement method: a case study with laboratory testing and in-situ verification for a highway project in southern Vietnam," Geotechnical Engineering, vol. 47, no. 1, pp. 45-49, 2016.

[12] A. Porbaha, "State of the art in deep mixing technology: part I. Basic concepts and overview," Proceedings of the Institution of Civil Engineers-Ground Improvement, vol. 2, no. 2, pp. 81-92, 1998.

[13] K. Yao, Y. Pan, L. Jia, J. T. Yi, J. Hu, and C. Wu, "Strength evaluation of marine clay stabilized by cementitious binder," Marine Georesources \& Geotechnology, vol. 2019, pp. 1-14, 2019.

[14] K. Yao, Q. Chen, H. Xiao, Y. Liu, and F. H. Lee, "Small-strain shear modulus of cement-treated marine clay," Journal of Materials in Civil Engineering, vol. 32, no. 6, Article ID 04020114, 2020.

[15] S. Horpibulsuk, R. Rachan, and A. Suddeepong, "Assessment of strength development in blended cement admixed Bangkok clay," Construction and Building Materials, vol. 25, no. 4, pp. 1521-1531, 2011.

[16] S. Horpibulsuk, N. Miura, H. Koga, and T. S. Nagaraj, "Analysis of strength development in deep mixing: a field study," Proceedings of the Institution of Civil Engineers - Ground Improvement, vol. 8, no. 2, pp. 59-68, 2004.

[17] S. Horpibulsuk, R. Rachan, and A. Suddeepong, "State of the art in strength development of soil-cement columns," Proceedings of the Institution of Civil Engineers - Ground Improvement, vol. 165, no. 4, pp. 201-215, 2012.

[18] K. Yao, Q. Chen, J. Ho, H. Xiao, and F. H. Lee, "Strain-dependent shear stiffness of cement-treated marine clay," Journal of Materials in Civil Engineering, vol. 30, no. 10, Article ID 04018255, 2018.

[19] K. Yao, N. Li, D.-H. Chen, and W. Wang, "Generalized hyperbolic formula capturing curing period effect on strength and stiffness of cemented clay," Construction and Building Materials, vol. 199, pp. 63-71, 2019.

[20] F. Sariosseiri and B. Muhunthan, "Effect of cement treatment on geotechnical properties of some Washington State soils," Engineering Geology, vol. 104, no. 1-2, pp. 119-125, 2009.

[21] S. Horpibulsuk, N. Miura, and T. S. Nagaraj, "Clay-WaterCement ratio identity for cement admixed soft clays," Journal 
of Geotechnical and Geoenvironmental Engineering, vol. 131, no. 2, pp. 187-192, 2005.

[22] S. Horpibulsuk, N. Miura, and T. S. Nagaraj, "Assessment of strength development in cement-admixed high water content clays with Abrams' law as a basis," Géotechnique, vol. 53, no. 4, pp. 439-444, 2003.

[23] T. Tsuchida and Y. X. Tang, "Estimation of compressive strength of cement-treated marine clays with different initial water contents," Soils and Foundations, vol. 55, no. 2, pp. 359-374, 2015.

[24] S. J. Abbey, S. Ngambi, and E. Ganjian, "Development of strength models for prediction of unconfined compressive strength of cement/byproduct material improved soils," Geotechnical Testing Journal, vol. 40, no. 6, pp. 928-935, 2017.

[25] T.-S. Tan, T.-L. Goh, and K.-Y. Yong, "Properties of Singapore marine clays improved by cement mixing," Geotechnical Testing Journal, vol. 25, no. 4, pp. 422-433, 2002.

[26] E. J. Chen, Y. Liu, and F.-H. Lee, "A statistical model for the unconfined compressive strength of deep-mixed columns," Géotechnique, vol. 66, no. 5, pp. 351-365, 2016.

[27] M. S. Pakbaz and M. Farzi, "Comparison of the effect of mixing methods (dry vs. wet) on mechanical and hydraulic properties of treated soil with cement or lime," Applied Clay Science, vol. 105, pp. 156-169, 2015.

[28] M. Kitazume and M. Terashi, The Deep Mixing Method, CRC Press, Boca Raton, FL, USA, 2013.

[29] Y. Yi, X. Zheng, S. Liu, and A. Al-Tabbaa, "Comparison of reactive magnesia- and carbide slag-activated ground granulated blastfurnace slag and Portland cement for stabilisation of a natural soil," Applied Clay Science, vol. 111, pp. 21-26, 2015.

[30] F. Collins and J. G. Sanjayan, "The challenge of the cement industry towards the reduction of greenhouse emissions," in Proceedings of the International Association for Bridge and Structural Engineers (IABSE) Symposium, Geneva, Switzerland, September 2015.

[31] K. Yao, W. Wang, N. Li, C. Zhang, and L. Wang, "Investigation on strength and microstructure characteristics of nano$\mathrm{MgO}$ admixed with cemented soft soil," Construction and Building Materials, vol. 206, pp. 160-168, 2019.

[32] W. Wang, Y. Li, K. Yao, N. Li, A. Zhou, and C. Zhang, "Strength properties of nano-MgO and cement stabilized coastal silty clay subjected to sulfuric acid attack," Marine Georesources \& Geotechnology, vol. 2019, pp. 1-10, 2019.

[33] T. T. Nhan, H. Matsuda, T. X. Thach, N. Dai Vien, and H. T. Thanh, "Strength of granulated blast furnace slag during hydration reaction process," in CIGOS 2019, Innovation for Sustainable Infrastructure, Springer, Berlin, Germany, 2020.

[34] A. K. Sharma and P. V. Sivapullaiah, "Ground granulated blast furnace slag amended fly ash as an expansive soil stabilizer," Soils and Foundations, vol. 56, no. 2, pp. 205-212, 2016.

[35] R. D. Hooton, "Canadian use of ground granulated blastfurnace slag as a supplementary cementing material for enhanced performance of concrete," Canadian Journal of Civil Engineering, vol. 27, no. 4, pp. 754-760, 2000.

[36] M. Elchalakani, T. Aly, and E. Abu-Aisheh, "Sustainable concrete with high volume GGBFS to build Masdar City in the UAE," Case Studies in Construction Materials, vol. 1, pp. 10-24, 2014.

[37] M. Shariq, J. Prasad, and H. Abbas, "Effect of GGBFS on age dependent static modulus of elasticity of concrete," Construction and Building Materials, vol. 41, pp. 411-418, 2013.
[38] M. Shariq, J. Prasad, and A. Masood, "Effect of GGBFS on time dependent compressive strength of concrete," Construction and Building Materials, vol. 24, no. 8, pp. 1469-1478, 2010.

[39] E. Celik and Z. Nalbantoglu, "Effects of ground granulated blastfurnace slag (GGBS) on the swelling properties of limestabilized sulfate-bearing soils," Engineering Geology, vol. 163, pp. 20-25, 2013.

[40] S. Wild, J. M. Kinuthia, R. B. Robinson, and I. Humphreys, "Effects of ground granulated blast furnace slag (GGBS) on the strength and swelling properties of lime-stabilized kaolinite in the presence of sulphates," Clay Minerals, vol. 31, no. 3, pp. 423-433, 1996.

[41] K. V. Manjunath, H. Shekhar, M. Kumar, P. Kumar, and R. Kumar, "Stabilization of black cotton soil using ground granulated blast furnace slag," in Proceedings of the International Conference on Advances in Architecture and Civil Engineering ( $A A R C V$ 2012), Bangalore, Karnataka, India, June 2012.

[42] D. C. Sekhar, S. Nayak, and H. K. Preetham, "Influence of granulated blast furnace slag and cement on the strength properties of lithomargic clay," Indian Geotechnical Journal, vol. 47, no. 3, pp. 384-392, 2017.

[43] T. T. Nhan, "Potential application of granulated blast furnace slag as an alternative geo-material for sustainable development in Vietnam," in Proceedings of the Basic Research in "Earth and Environmental Sciences", Kurdistan Region, Iraq, April 2019.

[44] N. Nguyen Thi, T. Phi Hong, and S. Bui Truong, "Utilizing coal bottom ash from thermal power plants in Vietnam as partial replacement of aggregates in concrete pavement," Journal of Engineering, vol. 2019, Article ID 3903097, 11 pages, 2019.

[45] N. T. Nu and B. T. Son, "An experimental study of reusing coal ash for base course of road pavement in Viet Nam," Electronic Journal of Geotechnical Engineering, vol. 24, no. 4, pp. 945-960.

[46] A. Farouk and M. M. Shahien, "Ground improvement using soil-cement columns: experimental investigation," Alexandria Engineering Journal, vol. 52, no. 4, pp. 733-740, 2013.

[47] R. P. Asturias and G. A. Lorenzo, "Unconfined compression behavior of cement treated non-plastic soil reinforced with small diameter steel bars," International Journal of Engineering \& Technology, vol. 15, no. 4, pp. 29-34, 2015.

[48] S. C. Hemant and K. V. Mahendra, "Strength characterisation of fibre reinforced cement-fly ash mixes," International Journal of Geosynthetics and Ground Engineering, vol. 1, no. 30, pp. 1-8, 2015.

[49] A. K. Pathak, V. Pandey, K. Murari, and J. P. Singh, "Soil stabilisation using ground granulated blast furnace slag," International Journal of Applied Engineering Research, vol. 4, pp. 164-171, 2014.

[50] S. P. Pathivada, Effects of Water-Cement Ratio on Deep Mixing Treated Expansive Clay Characteristics, The University of Texas, Arlington, TX, USA, 2007.

[51] S. Y. Liu, Y. J. Du, L. H. Han, and M. F. Gu, "Experimental study on the electrical resistivity of soil-cement admixtures," Environmental Geology, vol. 54, no. 6, pp. 1227-1233, 2008.

[52] A. Hammad, Evaluation of Soil-Cement Properties with Electrical Resistivity, Dalhousie University, Truro, Canada, 2013. 